\title{
Differential Responses of Methionine Sulfoxide Reductases A and $B$ to Anoxia and Oxidative Stress in the Freshwater Turtle Trachemys scripta
}

\author{
Melissa Reiterer, Lynsey Bruce and Sarah Milton* \\ Department of Biological Sciences, Florida Atlantic University, Boca Raton, FL 33431, USA; \\ mreitere@fau.edu (M.R.); lynseyebruce@gmail.com (L.B.) \\ * Correspondence: smilton@fau.edu; Tel.: +1-561-297-3331
}

check for

updates

Citation: Reiterer, M.; Bruce, L.; Milton, S. Differential Responses of Methionine Sulfoxide Reductases A and B to Anoxia and Oxidative Stress in the Freshwater Turtle Trachemys scripta. Metabolites 2021, 11, 458. https://doi.org/10.3390/ metabo11070458

Academic Editors

Matthew Pamenter and Ken Storey

Received: 2 June 2021

Accepted: 13 July 2021

Published: 16 July 2021

Publisher's Note: MDPI stays neutral with regard to jurisdictional claims in published maps and institutional affiliations.

Copyright: (C) 2021 by the authors. Licensee MDPI, Basel, Switzerland. This article is an open access article distributed under the terms and conditions of the Creative Commons Attribution (CC BY) license (https:// creativecommons.org/licenses/by/ $4.0 /)$.

\begin{abstract}
Oxidative stress has been acknowledged as a major factor in aging, senescence and neurodegenerative conditions. Mammalian models are susceptible to these stresses following the restoration of oxygen after anoxia; however, some organisms including the freshwater turtle Trachemys scripta can withstand repeated anoxia and reoxygenation without apparent pathology. T. scripta thus provides us with an alternate vertebrate model to investigate physiological mechanisms of neuroprotection. The objective of this study was to investigate the antioxidant methionine sulfoxide reductase system (Msr) in turtle neuronal tissue. We examined brain transcript and protein levels of MsrA and MsrB and examined the potential for the transcription factor FOXO3a to regulate the oxygen-responsive changes in Msr in vitro. We found that Msr mRNA and protein levels are differentially upregulated during anoxia and reoxygenation, and when cells were exposed to chemical oxidative stress. However, while MsrA and MsrB3 levels increased when cell cultures were exposed to chemical oxidative stress, this induction was not enhanced by treatment with epigallocatechin gallate (EGCG), which has previously been shown to enhance FOXO3a levels in the turtle. These results suggest that FOXO3a and Msr protect the cells from oxidative stress through different molecular pathways, and that both the Msr pathway and EGCG may be therapeutic targets to treat diseases related to oxidative damage.
\end{abstract}

Keywords: anoxia; antioxidant; epigallocatechin gallate; EGCG; FOXO3a; MsrA; MsrB

\section{Introduction}

Survival under physiologically stressful conditions such as ischemia, acidosis or hypoxia requires an ability to maintain cellular homeostasis, preventing or ameliorating the activation of cell death pathways while simultaneously upregulating pro-survival mechanisms. Several vertebrate species tolerate not just hypoxia but hours, days and even weeks of complete anoxia; among the best studied are the crucian carp (Carassius carassius) and several species of freshwater turtles, including the western painted turtle Chrysemys picta and the red-eared slider Trachemys scripta [1]. Both the fish and turtle species have evolved this tolerance in order to withstand long northern winters in frozen-over lakes and ponds, where the ice covering creates an extended period of low oxygen without access to the surface. A critical element for this extended anoxic survival is the ability to prevent cell death in the brain, as in mammals, the brain is considered to be the most anoxia-sensitive of all the organs, with a high oxygen demand and low buffering capacity [1]. Survival mechanisms of the turtle have been under investigation for nearly 40 years [2], with the past decade characterized by the increasing elucidation of cellular and subcellular mechanisms that permit cell survival without oxygen.

These processes are aimed not only at promoting cell survival during anoxia itself but also upon reoxygenation. After an anoxic event, reoxygenation occurs within $10 \mathrm{~min}$ in the turtle [3]. This suggests the potential for the rapid release of reactive oxygen species (ROS) that could overwhelm antioxidant defenses and result in cell damage or death. 
The turtle, however, is able to survive bouts of anoxia and reoxygenation without any signs of functional or cellular impairment $[4,5]$. Previous studies have demonstrated that ROS levels decrease to near zero by $4 \mathrm{~h}$ of anoxia in the turtle brain, and reoxygenation returns these only to normoxic levels [6]. The same pattern is observed in primary neuronal cell cultures [6], which suggests that the turtle can prevent ROS overproduction after reoxygenation, and/or that it has high innate defense mechanisms that can prevent or repair ROS damage [6]. Both of these have been shown to occur in the turtle brain [5,7,8], but the mechanisms are not fully elucidated and may be linked to the same protective mechanisms that allow them to survive anoxia, including upregulation of protective MAPK pathways $[9,10]$ and increased HSP expression [11], in addition to the high innate levels of antioxidants.

Along with exogenous or endogenous compounds that directly act to lower ROS levels, the methionine sulfoxide reductase system (Msr) functions to prevent or reverse protein modifications due to ROS oxidation [12]. The amino acid methionine (Met) is highly susceptible to oxidation and this reaction results in the formation of a diastereomeric mixture of methionine-S-sulfoxide (Met-S-(O)) and methionine-R-sulfoxide (Met- $R-(\mathrm{O})$ ) [13]. The Msr system reduces Met-O back to Met by two distinct enzyme families: methionine-S-sulfoxide reductase A (MsrA) reduces Met-S-(O), while methionine-R-sulfoxide reductase B (MsrB) reduces Met- $R-(\mathrm{O})$ [13-17]. The cyclic oxidation/reduction of Met residues protects cells by (1) the repair of important proteins, since the oxidation of Met residues can alter protein function and may be lethal for the cell unless a mechanism to repair them exists [18]; and (2) keeping critical proteins in their reduced form [19]. Of the two enzyme forms, MsrA has been studied the most extensively, while MsrB was discovered more recently [13] and is less studied in animal systems [20-22].

MsrA is found in a variety of tissues including liver, kidney and brain tissues [23] and, in mammals, has been found in both the mitochondria and the cytosol [24,25]. Previous studies suggested that MsrA has a critical role in protection against oxidative stress [23], as the overexpression of MsrA can increase the lifespan or resistance to oxidative stress in numerous model systems including transgenic flies [26], yeast [27], mice [23], rat cardiac myocytes [28], T-lymphocytes [29], PC12 cells [30], lens cells [31] and WI-38 SV40 fibroblast cells [32]. The knockdown of this gene has been observed to render lens cells more sensitive to oxidative stress [31], and its null mutation renders E. coli more sensitive to growth inhibition by $\mathrm{H}_{2} \mathrm{O}_{2}$ [33]. MsrA has also been found to play a role in protection against cardiac ischemia/reperfusion. Cultured cardiac myocytes subjected to ischemia/reoxygenation (I/R) showed protection against injury when overexpressing MsrA [28], while cardiac myocytes from MsrA knockout mice could not tolerate physical or oxidative stress [34].

Studies have also characterized MsrB in various organisms including bacteria $[35,36]$, yeast [37], mammals [38], and fruit flies [39]. In mammalian models, MsrB has been found in three isoforms: MsrB1, MsrB2 and MsrB3; MsrB3 has two variations: MsrB3A and MsrB3B [40]. Each isoform is found in different subcellular locations and therefore may have different functions. MsrB1 has been found to target the cytosol and the nucleus, MsrB2 and MsrB3B the mitochondria and MsrB3A the endoplasmic reticulum [13]; however, the potential role of the MsrBs in protection against oxidative stress and aging is not yet clear. Deletion or overexpression of MsrB alone in yeast cells had little impact on the lifespan, though MsrB deletion additively decreased the lifespan in an $m s r A-/ m s r B-$ double knockout mutant [41]; similarly, studies overexpressing mouse MsrB1, MsrB2 or Drosophila MsrB in fruit flies did not have an effect on the lifespan of the organisms [42,43]. On the other hand, overexpression of the human MsrB3A isoform in fruit flies extended their lifespan and delayed the decline in locomotor activity and fecundity in older flies [21], while the combination of caloric restriction and MsrB overexpression synergistically increased the lifespan in yeast [41]. Overexpression of MsrB2 was also found to promote cell survival against $\mathrm{H}_{2} \mathrm{O}_{2}$-mediated cell death and prevented mitochondrial membrane depolarization in the T-lymphocytic leukemia MOLT-4 cell line [44]. 
The molecular mechanisms of Msr regulation are also still under investigation; one suggested regulatory mechanism of MsrA is the transcription factor forkhead box O (FOXO), with FOXO3 mRNA highly expressed in the brain [45]. FOXO proteins are involved in a wide array of cellular functions including metabolism, proliferation, differentiation, autophagy, apoptosis, cell cycle, DNA damage/repair and lifespan regulation, as well as oxidative stress protection [46-48]. The antioxidant role of FOXO is one of its most crucial functions [49], through activation of major antioxidant enzymes such as MnSOD [50,51] and catalase [52-54]. In T. scripta, FOXO1 is anoxia-responsive in the liver, and FOXO3 was activated in the heart, kidney and liver in response to anoxia, with both increased nuclear levels and higher DNA binding activity [55]. This higher activity was reflected in enhanced levels of FOXO target genes in the liver including the cell cycle inhibitor p27(kip1) gene and catalase [55]. Studies in animal models suggested MsrA as another possible target gene of FOXO [56,57]. A study in C. elegans showed that daf-16, a homolog to the transcription factor FOXO3a, enhances MsrA transcription during conditions of oxidative stress [56]. In fruit flies, overexpression of the Drosophila foxo increases the expression levels of MsrA compared to controls [57], while null mutants have decreased expression. In the turtle, we recently showed that foxo3a transcript levels increase slightly but significantly in anoxia (1.4-fold over control), with a further increase to 2.7-fold upon reoxygenation; chemical oxidative stress induced an approximate 11-fold increase above basal, suggesting FOXO to be an important defense against oxidative stress [58]. Overexpression of human foxo3a in turtle brain cultures, and the pharmacological induction of native foxo3a via treatment with the green tea polyphenol epigallocatechin-3-gallate (EGCG) both greatly reduce cell death in the face of chemical oxidative stress as well [58], and in Caenorhabditis elegans, both the mean and maximum lifespan were increased when cultures were grown with EGCG, which increased nuclear FOXO [59]. Two putative FOXO transcription binding sites have been identified in the T. scripta MsrA promoter region (sequence kindly provided by Dr. Paul Kirchman), further suggesting that MsrA may be a possible target for FOXO regulation in this organism.

On the other hand, in other animal models, FOXO/DAF-16 is negatively regulated by PI3K-AKT [60] and upregulated by JNK [61,62]. The phosphorylation of FOXO by AKT prevents its translocation to the nucleus and thus inhibits its activity (reviewed in [63]). In T. scripta though, AKT levels during anoxia are upregulated, while JNK is downregulated, both in vivo and in vitro $[9,10]$, and blocking pAKT pharmacologically results in increased cell death, while blocking JNK decreases cell death [64]. In addition, earlier studies showed p-FOXO increases in the cytoplasmic fraction of the anoxic T. scripta brain in vivo in anoxia and after $4 \mathrm{~h}$ of anoxia/4 h of reoxygenation (Figure S1), suggesting inhibition of the transcription factor. Together, these would suggest that FOXO would not be the regulatory mechanism behind any changes in Msr. The purpose of this study was thus to determine if Msr levels are upregulated in T. scripta undergoing anoxia/reoxygenation, as freshwater turtles have high levels of other antioxidants. We examined both MsrA and MsrB transcript and protein levels in vivo and examined the potential for FOXO to be a regulator of Msr changes in vitro. While mammals exhibit three different isoforms of MsrB [17], other organisms have only one form, including yeast, fruit flies and nematodes [13]. As it is unknown what form(s) and localization of MsrB may be present in the turtle, results are presented for putative MsrB2 levels (based on primers from the freshwater turtle Chrysemys picta and binding of mammalian antibodies) as well as a putative MsrB3.

\section{Results}

We found that $m r s A$ and $m s r B 2$ transcript levels are differentially upregulated during anoxia and reoxygenation in the whole brain of the freshwater turtle Trachemys scripta, with $m s r A$ levels increasing 9-fold during anoxia, then decreasing during reoxygenation to only 2.5-fold higher than normoxia (Figure 1). The expression of $m s r B 2$ increased 2-fold during anoxia and increased further to 3-fold of normoxic controls during reoxygenation. MsrA whole brain protein levels reflect the trend evident in the mRNA transcripts during 
anoxia, with immunoblotting results suggesting MsrA increased nearly 7-fold over basal by $4 \mathrm{~h}$ of anoxia (Figure 2 and Figure S2). However, despite the decrease in mRNA upon reoxygenation, the MsrA protein levels remained near anoxic levels, at 6-fold over basal (Figure 2). Changes in putative MsrB2 protein levels were even more dramatic. By $4 \mathrm{~h}$ of anoxia, MsrB2 levels were nearly 8-fold higher than controls, with a further elevation to nearly 15-fold of basal upon reoxygenation (Figure 2 and Figure S3). Actin levels remained unchanged throughout each condition [65], suggesting that the change in Msr protein levels was specific and not due to a generalized protein response to anoxia/reoxygenation (Figure 2 and Figure S4).

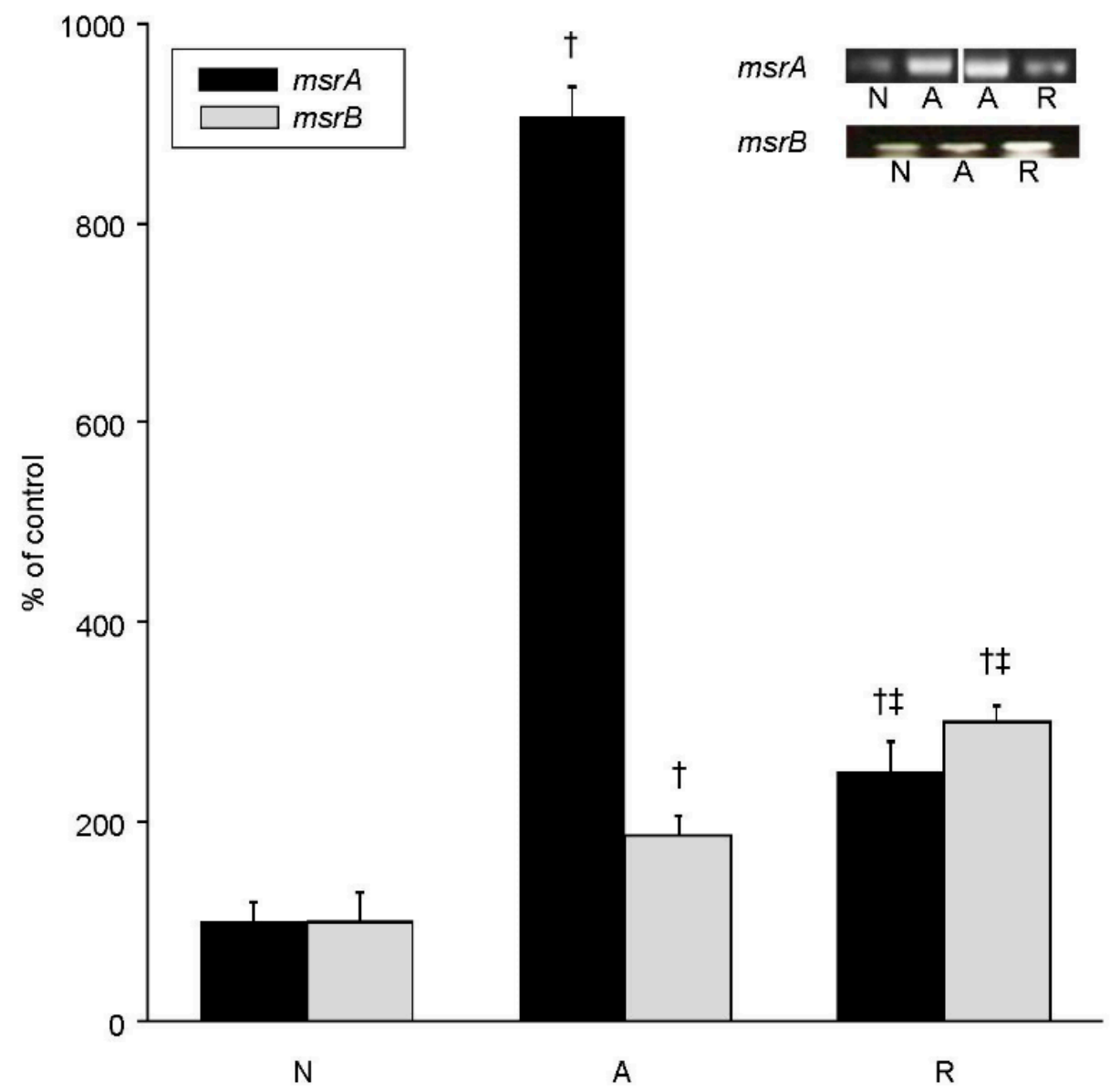

Figure 1. In vivo changes in $m s r A$ and $m s r B 2$ transcript levels in the whole brain of T. scripta. Representative gels of semi-quantitative RT-PCR for $m s r A$ and $m s r B 2$ and densitometric analysis of mRNA levels expressed as percent of normoxic control. $\mathrm{N}=$ normoxic controls, $\mathrm{A}=4 \mathrm{~h}$ of anoxia, $\mathrm{R}=4 \mathrm{~h}$ of anoxia $/ 4 \mathrm{~h}$ of reoxygenation. Statistics: $\dagger=$ significantly different from normoxic controls, $\ddagger=$ significantly different from anoxia ( $p<0.001, n=3-5$ individuals/treatment).

Even though the significant increases in Msr levels observed suggest a neuroprotective role for both MsrA and MsrB during anoxia and/or reoxygenation, the mechanism by which these increases occur is still unknown. Studies in C. elegans have shown that daf16, a homolog to the transcription factor FOXO3a, enhances MsrA transcription during conditions of oxidative stress, and in results already published, we showed that foxo3a transcript levels increase in vitro in anoxia and under conditions of oxidative stress [57] in primary cell cultures derived from whole turtle brains. As this increase protects the cells against severe oxidative stress, we thus looked to see if the same drivers of foxo expression would also affect Msr levels in whole brain primary cultures. 


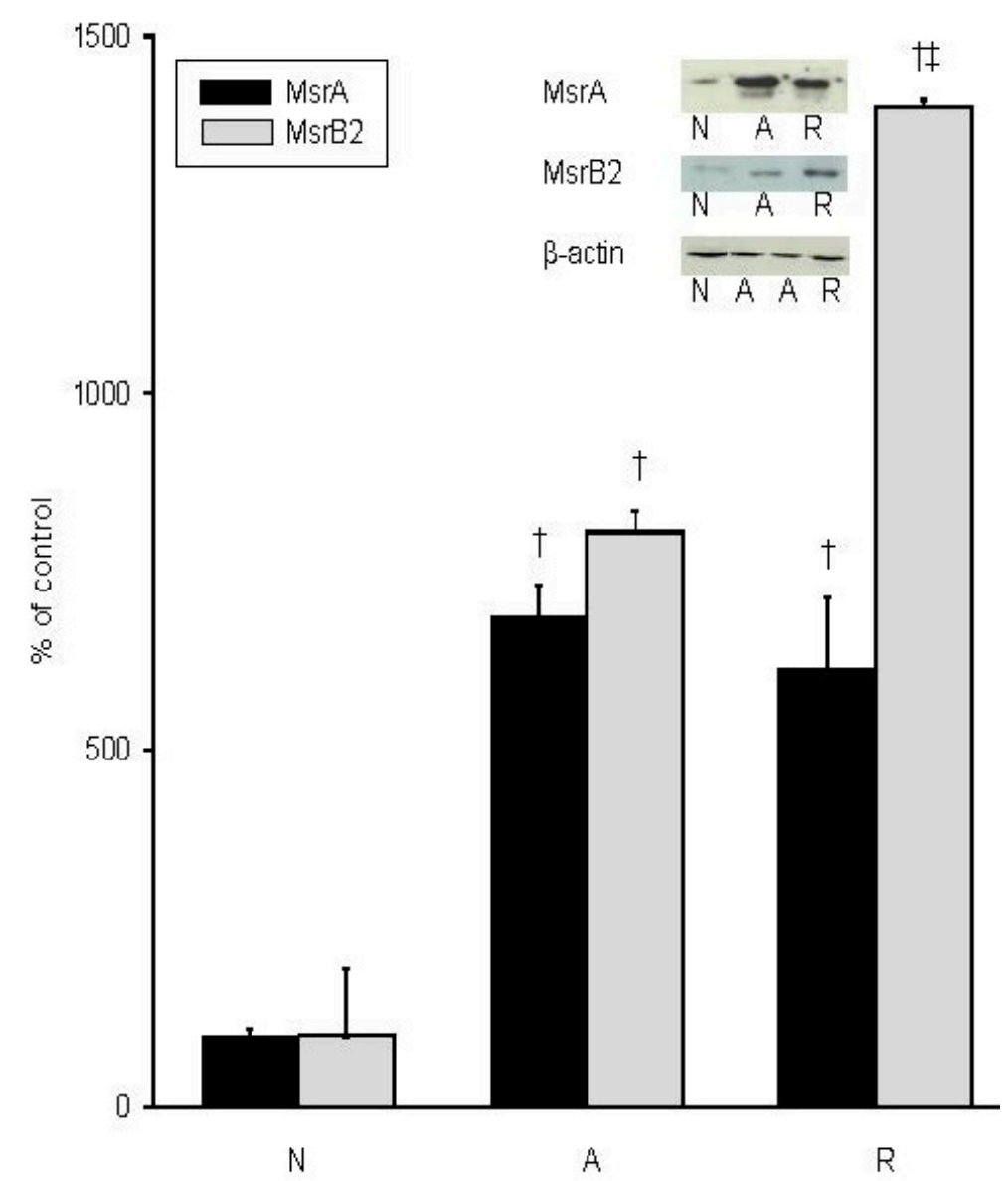

Figure 2. In vivo changes in Msr protein levels in the whole brain of T. scripta. Representative immunoblots of whole brain MsrA and MsrB2 proteins and actin control, and densitometric analysis of changes. $\mathrm{N}=$ normoxic controls, $\mathrm{A}=4 \mathrm{~h}$ of anoxia, $\mathrm{R}=4 \mathrm{~h}$ of anoxia $/ 4 \mathrm{~h}$ of reoxygenation. Statistics: $\uparrow=$ significantly different from normoxia; $\ddagger=$ significantly different from anoxia $(p<0.001$, $n=5$ individuals/treatment).

We demonstrated earlier that, while anoxia alone does not increase it, foxo3a expression in cultures made from the whole brain is upregulated 11-fold by exposure to $\mathrm{H}_{2} \mathrm{O}_{2}$, with even more significant increases when treated with EGCG in addition to $\mathrm{H}_{2} \mathrm{O}_{2}$ [58]. Extending that study, we found that the extensive upregulation of foxo $a$ in response to EGCG $+\mathrm{H}_{2} \mathrm{O}_{2}$ is not reflected in changes to $m s r A$ or $m s r B 3$ transcript levels as detected by quantitative PCR (Figure 3). While msr A levels are upregulated by the addition of $\mathrm{H}_{2} \mathrm{O}_{2}$ alone ( $6.0 \pm 0.3$-fold increase from basal), there was no additional increases resulting from EGCG exposure. Upregulation of $m s r A$ is observed only when cell cultures pre-treated with EGCG are also exposed to oxidative stress, and this upregulation is not significant compared to $\mathrm{H}_{2} \mathrm{O}_{2}$ treatment alone ( $20 \mu \mathrm{M}$ EGCG $5.1 \pm 0.5$-fold increase from basal), and is actually slightly but significantly lower in cell treated with $40 \mu \mathrm{M}$ EGCG plus $\mathrm{H}_{2} \mathrm{O}_{2}$ (3.4 \pm 0.8 -fold increase from basal) (Figure 3). Similarly, $m s r B 3$ levels are significantly upregulated from basal only when cells pre-treated with EGCG are also subjected to $\mathrm{H}_{2} \mathrm{O}_{2}$; however, this upregulation is also not significantly different from treatment with $\mathrm{H}_{2} \mathrm{O}_{2}$ alone $\left(\mathrm{H}_{2} \mathrm{O}_{2} 1.8 \pm 0.6\right.$-fold increase from basal, $20 \mu \mathrm{M} 2.7 \pm 0.3$-fold increase from basal and $40 \mu \mathrm{M} 2.6 \pm 0.3$-fold increase from basal) (Figure 3). Thus, the significant increases in foxo3a expression resulting from EGCG and oxidative stress are not reflected in similar increases in Msr expression, suggesting that these proteins are not downstream targets of FOXO in the turtle. 


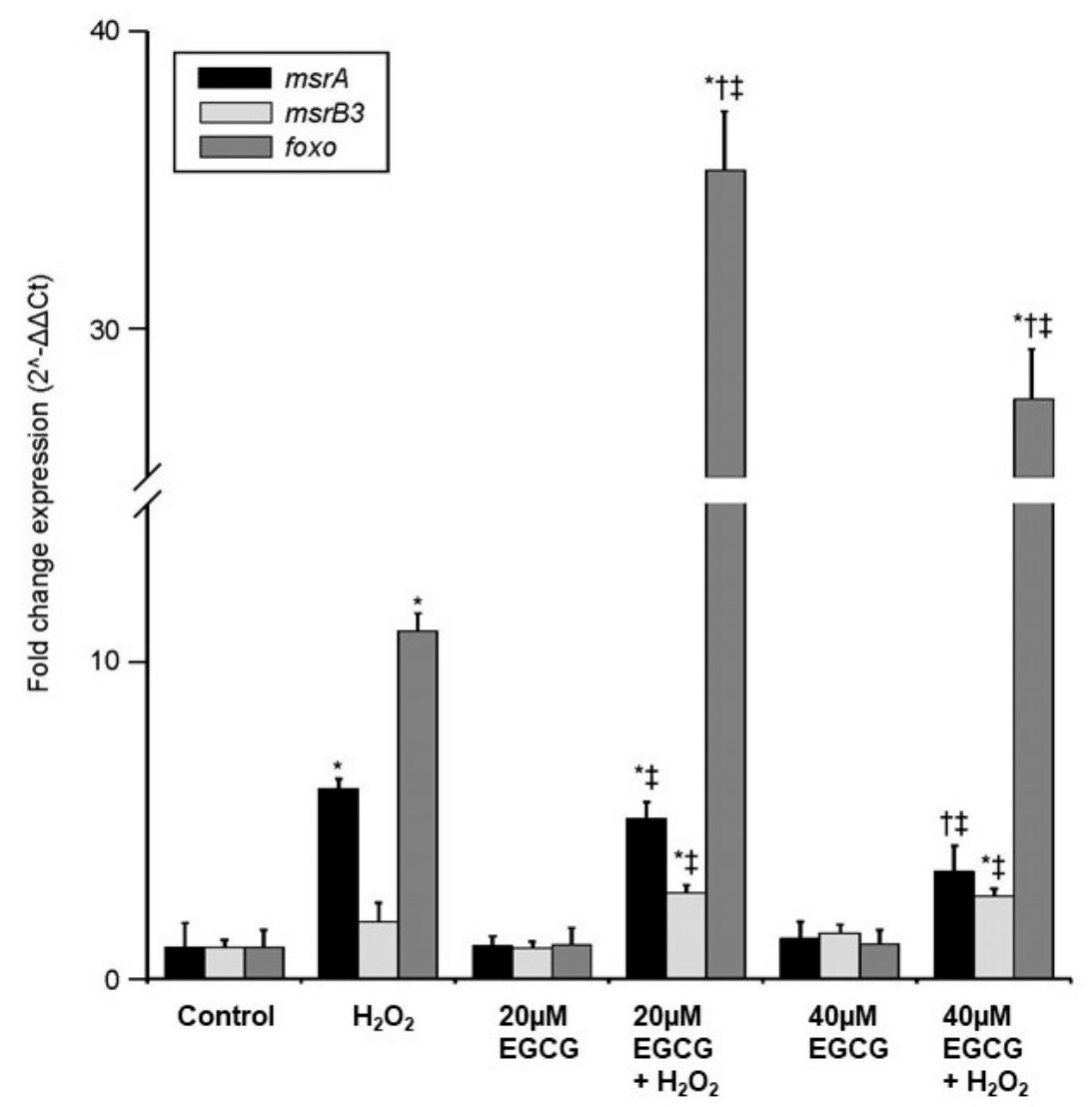

Figure 3. EGCG treatment does not enhance the upregulation of $m s r A$ or $m s r B 3$ under oxidative stress conditions in whole brain cell cultures. Msr $A$ and foxo3a, but not $m s r B 3$, levels are upregulated by $\mathrm{H}_{2} \mathrm{O}_{2}$ treatment, but EGCG treatment alone does not significantly affect $m s r A$, msrB3 or foxo3a expression. While pre-treatment with EGCG enhances the expression of foxo3a beyond stimulation with $\mathrm{H}_{2} \mathrm{O}_{2}$ alone, msrA expression in cultures treated with $20 \mu \mathrm{M}$ and $\mathrm{H}_{2} \mathrm{O}_{2}$ is no different than $\mathrm{H}_{2} \mathrm{O}_{2}$ alone, while $40 \mu \mathrm{M}$ EGCG plus $\mathrm{H}_{2} \mathrm{O}_{2}$ is slightly but significantly lower. $m s r B 3$ expression in cultures treated with either $20 \mu \mathrm{M}$ or $40 \mu \mathrm{M}$ EGCG and $\mathrm{H}_{2} \mathrm{O}_{2}$ is no different than $\mathrm{H}_{2} \mathrm{O}_{2}$ alone. * = significantly different from control, $\dagger=$ significantly different from $\mathrm{H}_{2} \mathrm{O}_{2}$ treatment, $\ddagger$ = significantly different from same EGCG treatment without $\mathrm{H}_{2} \mathrm{O}_{2}$. $(p<0.05)$. Foxo data modified from [58].

\section{Discussion}

Here, we provide evidence of oxygen-regulated changes in MsrA and MsrB transcript and protein levels in the turtle brain. While anoxia induced an upregulation of both MsrA and $\mathrm{MsrB}$, reoxygenation resulted in decreased $m s r A$ transcript levels, but a continued upregulation of $m s r B$, with protein levels for both remaining elevated above normoxic controls. While the general suppression of both transcription and protein synthesis is a key mechanism utilized to decrease the energy demand among invertebrate and vertebrate hypoxia-tolerant organisms [66-69], it is apparent from this and other studies that critical proteins in the turtle are upregulated against the general background of suppression in anoxia $[9,65,70,71]$. Such upregulation permits survival in the face of anoxia and potential ROS stress, and it has been suggested that high antioxidant levels, coupled to the ability to suppress ROS formation upon reoxygenation [6,72], may be an important part of turtle longevity as well [73]. The significant upregulation of both Msrs may contribute to this protection, as induction of MsrA has been shown to increase the lifespan in other animal models $[41,56]$. As it has been suggested in a variety of other organisms, the upregulation of such antioxidants during anoxia also supports the hypothesis that turtles exhibit the preparation for oxidative stress (POS) response, where adapted organisms prevent the accumulation of toxic ROS upon reoxygenation by increasing antioxidant defenses during the environmental stress event [74]. While the apparent protein level increases in MsrA 
and MsrB2 are both substantially greater than transcript levels, immunoblotting using mammalian antibodies in the turtle may not allow precise quantification of results; the increases in transcript levels may have resulted in more modestly elevated protein levels than reported here. Thus, while we are confident of the trends presented, it would be of interest for future work to measure specific enzyme activities of both MsrA and MsrB.

While we are currently investigating the function of the Msr proteins in the turtle brain, the differential changes suggest individual roles for MsrA and MsrB, with the substantial increase in MsrB under reoxygenation, in particular, suggesting a critical neuroprotective role during times of potential oxidative stress. Others investigating the role of MsrB as a protective mechanism against oxidative stress or aging in different model organisms reported mixed findings. Silencing any of the three mammalian forms of MsrB (-B1, -B2 or -B3) in human lens cells increased their sensitivity to oxidative stress-induced cell death [75], but in the fruit fly Drosophila melanogaster, some investigators reported that MsrB protects against oxidative stress and aging [21], and others reported that overexpression had no effect on the lifespan [43]. Bruce et al. [76], on the other hand, found that the lifespan was only affected when both $m s r A$ and $m s r B$ were deleted in D. melanogaster.

While the protective effect of the Msr family has been well described in multiple organisms from bacteria to mice [26,31,34,41,77], the mechanism which regulates Msr transcription and translation has been far less studied. The only other vertebrate thus far to also show an oxygen-responsive regulation of Msr during hypoxia is the subterranean mole rat Spalax galili [78], which is also tolerant to severe hypoxia [79,80]. In other organisms, hypoxia inducible factor HIF-1 $\alpha$ has been suggested as a possible MsrA regulator due to its role in the upregulation of multiple protective genes during hypoxia $[81,82]$. However, HIF-1 $\alpha$ transcript levels do not increase in the anoxic turtle [83], nor do protein levels even over $24 \mathrm{~h}$ of anoxia or upon reoxygenation [84]. Earlier results from our lab, in fact, showed that HIF-1 $\alpha$ disappears from the nuclear fraction of neuronal cultures in anoxia (Milton, unpublished data), and rather than being protective, stimulation of HIF$1 \alpha$ expression pharmacologically with tilorone increased cell death in a dose-dependent manner, concomitant with an increase in anoxic HIF-1 $\alpha$ levels in the nucleus [84]. Studies in similarly anoxia-tolerant crucian carp have shown that HIF-1 DNA binding activity in severely hypoxic warm-acclimated $\left(26^{\circ} \mathrm{C}\right)$ fish also remained unaltered in all tissues studied [85]. As many of the pro-survival pathways upregulated by HIF-1 in hypoxia in mammalian models are conversely downregulated in good facultative anaerobes as a means to conserve energy in a deeply depressed metabolic state [1], the lack of a strong HIF-1 response in anoxia in these models is unsurprising.

As the lack of an increase in HIF-1 $\alpha$ when Msr levels are changing in both anoxia and reoxygenation suggests, therefore, that this transcription factor is unlikely to be the regulator of oxygen-modulated Msr expression, we investigated whether Msr levels might, instead, be affected by the transcription factor FOXO3a, as its homolog daf-16 is involved in the regulation of MsrA expression in C. elegans [56]. In addition, knockdown of FOXO decreased both MsrA and MsrB mRNA levels and abolished the induction by paraquat of both Msrs in the red flour beetle [86]. An analysis of upstream regulatory sequences of the turtle $m s r A$ gene also suggested the presence of candidate FOXO binding sites (Kirchman, pers. comm.).

FOXO3a has also been demonstrated to render protection through the upregulation of other antioxidant enzymes such as Mn SOD [50,51,87] and CAT [52,53,88] during conditions of oxidative stress, and in mammalian models, oxidative stress or heat shock results in the movement of FoxO3a from the cytoplasm to the nucleus $[89,90]$. The catalase gene also appears to be one target of anoxia-induced upregulation of FOXO3 in the nucleus of turtle kidney, heart and liver cells [55]. In addition, foxo3a levels in turtle brain cultures are significantly upregulated during reoxygenation and are protective against chemical oxidative stress [58]. Based on these studies and on the putative binding sites of FOXO3a on the MsrA promoter, FOXO3a appeared to be a good candidate for the regulator of Msr expression, but the results of this study suggest otherwise. In this study, however, we found 
that pharmacological manipulation of FOXO3a with EGCG increased its expression during oxidative stress conditions but did not result in an increased expression of either MsrA or MsrB. The data thus imply that FOXO3a and Msr operate by separate molecular pathways in this model, at least in brain tissue. As it was suggested by Krivoruchko and Storey [55] in other turtle organs in anoxia, FOXO3a may be protecting the cells by activating other target genes involved in different cellular processes that have the common end goal of cellular protection and survival [87-89,91-93].

The mechanisms behind MsrB's responses to oxidative stress are even less studied than for MsrA. A study in E. coli demonstrated that the antibiotic fusaricidin A can activate both recombinant MsrA and MsrB [94], while in fruit flies, it is under hormonal control [95]. In this study, the MsrB protein levels appeared to change more significantly than the MsrB messenger level, suggesting that there is regulation of MsrB activity at the translational level or in the rate of protein degradation. Picot et al. [96] reported decreases in both mitochondrial and cytosolic MsrA activity during ischemia and early reperfusion in the rat heart, though there was no change in Msr levels, which suggests further regulation at the translational level is possible, and in mammalian models, the decrease in MsrA activity would diminish the cellular antioxidant response and reduce recovery. Since it has also been reported that MsrB expression may be controlled by MsrA expression [97], the MsrA increases in the anoxic turtle brain could also have led to the continued elevation in MsrB expression. The significant changes to the Msrs, and the likelihood that they play an important role in resistance to hypoxia, anoxia and/or oxidative stress suggest it would be of interest to further investigate the relationship between Msr and other neuroprotective mechanisms that are activated during anoxia and reoxygenation, as well as determining the underlying regulatory mechanism. While this study focused on FOXO3a, there is, of course, a suite of other transcription factors that could potentially play this role.

These observations further elucidate cell survival pathways in response to hypoxia/ ischemia and may lead to novel therapeutics based on the repair of methionine oxidation in key survival pathways. Understanding the neuroprotective mechanisms in the turtle could reveal new possibilities for defense against hypoxia/anoxia and oxidative stress in mammalian models and may help determine future strategies to ameliorate the damaging effects of ROS overproduction, along with the neuropathologies associated with protein oxidation [98]. This vertebrate system, in which Msr is upregulated in response to physiological conditions, provides a unique model in which to further examine the signal transduction pathways that regulate Msr expression. In addition, the protective role of EGCG and its ability to upregulate FOXO suggest it should be further studied as a therapeutic target to treat diseases of oxidative stress.

\section{Materials and Methods}

This study was approved by the Florida Atlantic University Institutional Animal Care and Use Committee as IACUC protocols A15-35 and A18-38, approved 10/2015 and renewed $10 / 2018$.

\subsection{Animals}

Freshwater turtles (Trachemys scripta) weighing 300-500 g were obtained from commercial suppliers (Clive Longdon, Tallahassee, FL, USA; Niles Biological, Inc., Sacramento, CA, USA) and kept in freshwater aquaria in an in-lab facility on a $12 \mathrm{~h}$ light/dark cycle. Animals were fed three times weekly to satiety with commercial turtle food.

\subsection{Protein Extraction from Whole Brain}

Turtles were individually placed in sealed $2 \mathrm{~L}$ plastic chambers at room temperature $\left(24 \pm 1^{\circ} \mathrm{C}\right)$. The three experimental sets $(n=5)$ included normoxic controls, anoxic animals exposed to 4 h of $99.99 \% \mathrm{~N}_{2}$ (positive pressure flow-through, Air Gas, Miami, FL, USA) and a third group of $4 \mathrm{~h}$ of anoxia/ $4 \mathrm{~h}$ of normoxic recovery in room air. Normoxic control animals were taken directly from aquaria. Animals were then sacrificed by decapitation, 
and the brains were immediately homogenized for protein extraction. Whole brains were homogenized and extracted with $200 \mu \mathrm{L}$ lysis buffer ( 5 mM EDTA, pH 8.0, $0.15 \mathrm{M} \mathrm{NaCl}, 1 \%$ Triton X-100, $10 \mathrm{mM}$ Tris-Cl pH 7.4), as previously described [70]. Protein concentrations were determined using a standard BCA assay following the manufacturer's protocol (Pierce Biotechnology, Inc., Rockville, IL, USA).

\subsection{Cell Culture Cultivation and Treatment}

For whole brain cell cultures, the cortex of the turtle brain was aseptically chopped and added to a cocktail of MEM, $0.16 \mathrm{U} / \mathrm{mL}$ Dispase (Gibco, Waltham, MA, USA), $12.5 \mathrm{U} / \mathrm{mL}$ Collagenase (Gibco) and $6.25 \mathrm{mg} / \mathrm{mL}$ Hyalurondinase (Sigma-Aldrich, St. Louis, MO, USA). The solution was placed on a rocker for $4 \mathrm{~h}$ at $37^{\circ} \mathrm{C}$ and resuspended every $15 \mathrm{~min}$ for $1 \mathrm{~h}$. The homogenate was then centrifuged at $750 \times g$ for $6 \mathrm{~min}$, the supernatant was discarded and the pellet was washed with fresh MEM. A second centrifugation at $750 \times g$ for 6 min was performed, the supernatant was discarded and the pellet was removed and placed into MEM with 10\% FBS and 1\% Pen/Strep and then plated into 6-well plate culture dishes. The media in each well were changed on the following day and weekly afterwards. Cell cultures were grown for 3 weeks at $30{ }^{\circ} \mathrm{C}$ in a $5 \% \mathrm{CO}_{2}$ incubator. Anoxia and anoxia/reoxygenation in cell cultures were induced in a Shel-Lab Bactron anaerobic chamber (Sheldon Manufacturing Inc. Cornelius, OR, USA) at $30^{\circ} \mathrm{C}$ under an anoxic gas mixture $\left(90 \% \mathrm{~N}_{2}, 5 \% \mathrm{He}, 5 \% \mathrm{CO}_{2}\right.$, AirGas, Miami, FL, USA), as previously described [10]. An OM-4 oxygen meter (Microelectrodes Inc., Bedford, NH, USA) was used to continuously monitor oxygen levels within the chamber. Control cultures were used directly from the incubator.

\subsection{Protein Extraction from Culture}

Protein was extracted from cell cultures $(n=5)$ using RIPA lysis buffer $(0.15 \mathrm{M} \mathrm{NaCl}$; 5 mM EDTA, pH 8.0; 1\% Triton X100; 10 mM Tris-Cl, pH 7.4), and 5 M DTT, 100 mM PMSF and $5 \mathrm{M}$ mercaptoethanol at a 1:1000 ratio of the RIPA lysis buffer. Cells were scraped using sterile cell scrapers and allowed to incubate on ice for $10 \mathrm{~min}$ before being centrifuged at $18,500 \times g$ for $10 \mathrm{~min}$ at $4^{\circ} \mathrm{C}$, and the supernatant was collected. The protein concentration was determined using a standard BCA Protein Assay (Pierce Biotechnology).

\subsection{RT-PCR}

Total RNA was extracted using TRIzol reagent (Life Technologies, Grand Island, NY, USA) and treated with DNase I. RNA quality was analyzed on a $1 \%$ denaturating EtBragarose gel, and the quantity was measured using Gene Quant pro (Amersham Pharmacia Biotech, Uppsala, Sweden). For MsrA, cDNA was synthesized from total RNA using a random MsrA forward primer for MsrA, and an actin forward primer for actin. The PCR reactions using Taq polymerase were as follows: MsrA: denaturation for $3 \mathrm{~min}, 95{ }^{\circ} \mathrm{C}$; PCR: 45 cycles $\left(3 \mathrm{~min}, 95^{\circ} \mathrm{C} ; 30 \mathrm{~s}, 59{ }^{\circ} \mathrm{C}\right.$; $1 \mathrm{~min}, 72{ }^{\circ} \mathrm{C}$ ), followed by elongation: $10 \mathrm{~min}$, $72{ }^{\circ} \mathrm{C}$. MsrB: denaturation for $7 \mathrm{~min}, 94{ }^{\circ} \mathrm{C}$; PCR: 40 cycles $\left(1 \mathrm{~min}, 94{ }^{\circ} \mathrm{C}\right.$; $45 \mathrm{~s}, 55^{\circ} \mathrm{C}$; $1.0 \mathrm{~min}, 72{ }^{\circ} \mathrm{C}$ ), followed by elongation: $10 \mathrm{~min}, 72{ }^{\circ} \mathrm{C}$. For actin, PCR was conducted for 40 cycles $\left(1 \mathrm{~min}, 94^{\circ} \mathrm{C}\right.$; $\left.2 \mathrm{~min}, 57^{\circ} \mathrm{C} ; 3 \mathrm{~min}, 72^{\circ} \mathrm{C}\right)$. The following primers were employed: MsrA: 5'-TTCTGTTGTGATT-GTGCCAAA-3' (forward) and 5'-GGACACAGATGGTTTTATTTGGT-3' (reverse); actin primers: 5'-CACCAACTGGGACGACATGG-3' (forward) and 5'-GTCGGC-CAGCTCGTAGCTCT-3' (reverse). For MsrB, a comparative alignment was performed between species (E. coli, mouse, human) where MsrB has been sequenced, searching for conserved regions using ClustalX v.1.81 and Genedoc v.2.6.002 (http: / / www.psc.edu/biomed/genedoc, accessed on 16 February 2009). Primers specific to turtle MsrB cDNA were designed from a partial cDNA sequence that was obtained previously by RT-PCR analysis of turtle brain mRNA using degenerate primers homologous to MsrB sequences from frog, mouse and human. Turtle brain-specific MsrB primers were: 5'-TCCACGTTAGTCCCTGTTCA-3' (forward) and 5'-CTTTGAGCGTCTCGAATCT-3' (reverse). Controls in which RNA or RT was omitted from the RT reaction were carried out to 
confirm the absence of residual genomic DNA. Following electrophoresis of PCR products, gels were stained with ethidium bromide and digitally photographed for quantification using NIH Image J 1.60 software. For semi-quantitative assessment of MsrA and MsrB RT-PCR, signal intensities were expressed as a ratio of levels of PCR products amplified from turtle actin cDNAs.

\subsection{Immunoblotting}

Equal amounts of protein from cell lysates were separated electrophoretically by SDSPAGE (12\%) at $150 \mathrm{~V}$ for $1 \mathrm{~h}$ and subsequently transferred to nitrocellulose membranes (Hybond ECL, Amersham Biosciences, Piscataway, NJ, USA). Actin (Sigma-Aldrich; 1:3000) was used as a control in all instances to verify equal loading of proteins. Membranes were blocked in $5 \%$ nonfat dried milk in Tris-buffered saline ( $25 \mathrm{mM}$ Tris-Cl, $\mathrm{pH} 7.5$, at $24{ }^{\circ} \mathrm{C}, 150 \mathrm{mM} \mathrm{NaCl}$ ) with $0.1 \%$ Tween 20 for $1 \mathrm{~h}$ at room temperature. Primary antibodies were diluted in $5 \%$ milk and incubated overnight at $4{ }^{\circ} \mathrm{C}$. The primary antibodies used included: methionine sulfoxide reductase A (Abcam, Cambridge, MA, USA; 1:1000), MsrB2 (Epitomics, Burlingame, CA, USA, 1:1000) and $\beta$-actin (Abcam, 1:3000). Secondary antibodies (goat anti-rabbit and rabbit anti-mouse) were obtained from Southern Biotech (Birmingham, AL, USA). The membranes were washed $3 \times$ with TBST and incubated for $1 \mathrm{~h}$ with an HRP-conjugated secondary antibody (Southern Biotech; Millipore, Billerica, MA, USA) diluted in 5\% milk. The protein-antibody complexes were visualized by ECL chemiluminescence (Amersham Biosciences, Amersham, HP, UK) and quantified by relative densitometry using NIH ImageJ image analysis software. Preliminary runs established the range of protein loading and antibody concentrations to remain in the linear range of the signal (Figure S5). Results were normalized to percent of actin (no change in anoxia, relative changes expressed as percent of control (Figure 2 and Figure S4)).

\subsection{Chemical Oxidative Stress}

As turtle cell cultures are not susceptible to damage by straightforward anoxia/ reoxygenation, we utilized $1.4 \mathrm{mM} \mathrm{H}_{2} \mathrm{O}_{2}$ as chemical oxidative stress, as previously described [58]. This resulted in $\sim 75 \%$ cell death within $30 \mathrm{~min}$. Cell cultures where then extracted for RNA isolation.

\subsection{Pharmacological Stimulation of FOXO3a with EGCG}

EGCG was purchased from SigmaAldrich (St Louise, MO, USA). Cell cultures were grown to $50-70 \%$ confluency and exposed to the following treatments: $1.4 \mathrm{mM} \mathrm{H}_{2} \mathrm{O}_{2}, 20 \mu \mathrm{M}$ EGCG, $20 \mu \mathrm{M}$ EGCG $+1.4 \mathrm{mM} \mathrm{H}_{2} \mathrm{O}_{2}, 40 \mu \mathrm{M}$ of EGCG and $40 \mu \mathrm{M}$ of EGCG $+1.4 \mathrm{mM}$ $\mathrm{H}_{2} \mathrm{O}_{2}$, as previously described [58]. Concentrations of $20 \mu \mathrm{M}$ and $40 \mu \mathrm{M}$ of EGCG were used as these concentrations did not appear to have any negative effects on the cultures (no cell death or change in morphology). Incubation was performed in a rocker at room temperature for $4 \mathrm{~h}$ (for EGCG) with an additional $30 \mathrm{~min}$ for $\mathrm{H}_{2} \mathrm{O}_{2}$ exposure. Cells were then extracted for RNA isolation.

\subsection{Reverse Transcription and QPCR}

RT was performed using iScript ${ }^{\mathrm{TM}}$ Reverse Transcription Supermix for RT-qPCR (BioRad, Hercules, CA, USA) following the manufacturer's protocol. Briefly, $1 \mu \mathrm{g}$ of RNA was mixed with iScript ${ }^{\mathrm{TM}}$ Supermix and water to a volume of $20 \mu \mathrm{L}$, followed by $5 \mathrm{~min}$ incubation at $25{ }^{\circ} \mathrm{C}$ for priming, $20 \mathrm{~min}$ at $46^{\circ} \mathrm{C}$ for reverse transcription and $1 \mathrm{~min}$ at $95^{\circ} \mathrm{C}$ for RT inactivation.

QPCR was performed using SsoAdvanced ${ }^{\mathrm{TM}}$ Universal SYBR $^{\circledR}$ Green Supermix (BioRad, Hercules, CA, USA). An amount of 100 ng of cDNA template was mixed with $2 \times$ SYBR Green, $100 \mu \mathrm{M}$ of Forward and Reverser Primers and $\mathrm{H}_{2} \mathrm{O}$. The amplification cycle consisted of $3 \mathrm{~min}$ initial denaturation at $95{ }^{\circ} \mathrm{C}$, followed by 45 cycles of $95{ }^{\circ} \mathrm{C}$ for $30 \mathrm{~s}$ and $60{ }^{\circ} \mathrm{C}$ for $1 \mathrm{~min}$. Turtle-specific primers were created using the PrimerQuest Design tool from Integrated DNA Technologies (Skokie, IL, USA). Actin 
primers were designed based on the Chrysemys picta genome; MsrA and MsrB3 primers were designed based on a T. scripta sequence kindly provided by Dr. Kirchman. The following primers were used: MsrA: 5'-TGACCCGACACAAGGAATGAGGCAAGG$3^{\prime}$ (forward) and 5'-TGATTGTGCCAAAACCGCTCTCCGT-CA-3' (reverse); MsrB3: 5' AAGGTGGTCT TTTCCCAGCA-3' (forward) and 5'-GGAGTTCCACAGACAACACAT$3^{\prime}$ (reverse); FOXO3a: 5'-CTCAGTCCAACCAGGGAAGTTTG-3' (forward) and $5^{\prime}-$ GGTGACTGCTGCTGGTGTTT-3' (reverse); actin 5'-CACCACAG-CCGAAAGGGAAAT-3' (forward) and 5'-CATCAGGGAG TTCGTAGCTCTTCT-3' (reverse). Actin was used as a housekeeping gene as there is no change in its expression during anoxia.

\subsection{Statistical Analysis}

Statistical significance was evaluated using ANOVA followed by Tukey's post hoc test. A value of $p<0.05$ was used to denote statistical significance, and results are expressed as mean \pm S.E.M. All statistics were carried out using SigmaPlot 11.0 (Systat Software Inc., San Jose, CA, USA) statistical software.

Supplementary Materials: The following are available online at https:/ / www.mdpi.com/article/ 10.3390/metabo11070458/s1, Figure S1: Immunoblots from 3 individual turtles suggesting some increase in phosphorylated FOXO (p-FOXO) in the cytoplasm (cyto) of the anoxic and anoxic/ reoxygenated turtle T. scripta, Figure S2: Upper panels: Western blot of MsrA and actin (as loading control) from whole brains of 3 different turtles. Lower panels: Western blot showing MsrA levels from whole brains of 2 turtles, with cells fractionated into cytoplasmic and mitochondrial compartments, Figure S3: Original immunoblot for MsrB2, Figure S4: Original immunoblot of housekeeping protein $\beta$-actin in 4-5 individuals under conditions of normoxia $(\mathrm{N}), 4 \mathrm{~h}$ of anoxia $(\mathrm{A})$ and $4 \mathrm{~h}$ of anoxia/4 h of reoxygenation (R), Figure S5: Immunoblotting for MsrB2. Preliminary work was investigating if Msr levels varied differently between the cytoplasmic (" $\mathrm{C}$ " lanes) and mitochondrial ("M" lanes) compartments in response to anoxia or anoxia/reoxygenation.

Author Contributions: Conceptualization: S.M. and M.R.; methodology: S.M., L.B. and M.R.; investigation: L.B. and M.R.; resources: S.M.; data curation: S.M., L.B. and M.R.; writing—original draft preparation: M.R. and S.M.; writing—review and editing: S.M.; project administration: S.M.; funding acquisition: S.M. All authors have read and agreed to the published version of the manuscript.

Funding: This research was funded by the National Institute of Health grant number 1R15AG03337401 to SLM and by the FAU Foundation.

Institutional Review Board Statement: This study was approved by the Florida Atlantic University Institutional Animal Care and Use Committee as IACUC protocols A15-35 and A18-38, approved October 2015 and renewed October 2018.

Informed Consent Statement: Not applicable.

Data Availability Statement: Data are contained within the article and Supplementary Materials.

Acknowledgments: Thank you to Itzel Sifuentes-Romero and Howard Prentice for assisting in primer design, and to Gauri Nayak for the original MsrB blots.

Conflicts of Interest: The authors declare no conflict of interest.

\section{References}

1. Lutz, P.L.; Nilsson, G.E.; Prentice, H.M. The Brain without Oxygen, 3rd ed.; Kluwer Academic Publishers: Boston, MA, USA, 2003; ISBN 1-4020-1165-2.

2. Hochachka, P.W. Defense strategies against hypoxia and hypothermia. Science 1986, 231, 234-241. [CrossRef]

3. Fernandes, J.A.; Lutz, P.L.; Tannenbaum, A.; Todorov, A.T.; Liebovitch, L.; Vertes, R. Electroencephalogram activity in the anoxic turtle brain. Am. J. Physiol. 1997, 273, R911-R919. [CrossRef] [PubMed]

4. Warren, D.E.; Jackson, D.C. The metabolic consequences of repeated anoxic stress in the western painted turtle, Chrysemys picta bellii. Comp. Biochem. Physiol. Part. A Mol. Integr. Physiol. 2017, 203, 1-8. [CrossRef] [PubMed]

5. Rice, M.E.; Lee, E.J.; Choy, Y. High levels of ascorbic acid, not glutathione, in the CNS of anoxia-tolerant reptiles contrasted with levels in anoxia-intolerant species. J. Neurochem. 1995, 64, 1790-1799. [CrossRef] [PubMed] 
6. Milton, S.L.; Nayak, G.; Kesaraju, S.; Kara, L.; Prentice, H.M. Suppression of reactive oxygen species production enhances neuronal survival in vitro and in vivo in the anoxia-tolerant turtle Trachemys scripta. J. Neurochem. 2007, 101, 993-1001. [CrossRef] [PubMed]

7. Willmore, W.G.; Storey, K.B. Antioxidant systems and anoxia tolerance in a freshwater turtle Trachemys scripta elegans. Mol. Cell. Biochem. 1997, 170, 177-185. [CrossRef] [PubMed]

8. Willmore, W.G.; Storey, K.B. Glutathione systems and anoxia tolerance in turtles. Am. J. Physiol. 1997, 273, R219-R225. [CrossRef] [PubMed]

9. Milton, S.L.; Dirk, L.J.; Kara, L.F.; Prentice, H.M. Adenosine modulates ERK1/2, PI3K/Akt, and p38MAPK activation in the brain of the anoxia-tolerant turtle Trachemys scripta. J. Cereb. Blood Flow Metab. 2008, 28, 1469-1477. [CrossRef]

10. Nayak, G.H.; Prentice, H.M.; Milton, S.L. Neuroprotective signaling pathways are modulated by adenosine in the anoxia tolerant turtle. J. Cereb. Blood Flow Metab. 2011, 31, 467-475. [CrossRef]

11. Kesaraju, S.; Nayak, G.; Prentice, H.M.; Milton, S.L. Upregulation of Hsp72 mediates anoxia/reoxygenation neuroprotection in the freshwater turtle via modulation of ROS. Brain Res. 2014, 1582, 247-256. [CrossRef]

12. Oien, D.; Moskovitz, J. Protein-carbonyl accumulation in the non-replicative senescence of the methionine sulfoxide reductase A (msrA) knockout yeast strain. Amino Acids 2007, 32, 603-606. [CrossRef] [PubMed]

13. Kim, H.-Y.; Gladyshev, V.N. Methionine sulfoxide reduction in mammals: Characterization of methionine-R-sulfoxide reductases. Mol. Biol. Cell 2004, 15, 1055-1064. [CrossRef] [PubMed]

14. Weissbach, H.; Etienne, F.; Hoshi, T.; Heinemann, S.H.; Lowther, W.T.; Matthews, B.; St John, G.; Nathan, C.; Brot, N. Peptide methionine sulfoxide reductase: Structure, mechanism of action, and biological function. Arch. Biochem. Biophys. 2002, 397, 172-178. [CrossRef] [PubMed]

15. Delaye, L.; Becerra, A.; Orgel, L.; Lazcano, A. Molecular evolution of peptide methionine sulfoxide reductases (MsrA and MsrB): On the early development of a mechanism that protects against oxidative damage. J. Mol. Evol. 2007, 64, 15-32. [CrossRef]

16. Minetti, G.; Balduini, C.; Brovelli, A. Reduction of DABS-L-methionine-DL-sulfoxide by protein methionine sulfoxide reductase from polymorphonuclear leukocytes: Stereospecificity towards the L-sulfoxide. Ital. J. Biochem. 1994, 43, $273-283$.

17. Achilli, C.; Ciana, A.; Minetti, G. The discovery of methionine sulfoxide reductase enzymes: An historical account and future perspectives. BioFactors 2015, 41, 135-152. [CrossRef]

18. Lee, J.W.; Gordiyenko, N.V.; Marchetti, M.; Tserentsoodol, N.; Sagher, D.; Alam, S.; Weissbach, H.; Kantorow, M.; Rodriguez, I.R. Gene structure, localization and role in oxidative stress of methionine sulfoxide reductase A (MSRA) in the monkey retina. Exp. Eye Res. 2006, 82, 816-827. [CrossRef]

19. Levine, R.L.; Mosoni, L.; Berlett, B.S.; Stadtman, E.R. Methionine residues as endogenous antioxidants in proteins. Proc. Natl. Acad. Sci. USA 1996, 93, 15036-15040. [CrossRef]

20. Jung, S.; Hansel, A.; Kasperczyk, H.; Hoshi, T.; Heinemann, S.H. Activity, tissue distribution and site-directed mutagenesis of a human peptide methionine sulfoxide reductase of type B: hCBS1. FEBS Lett. 2002, 527, 91-94. [CrossRef]

21. Lim, D.-H.; Han, J.Y.; Kim, J.-R.; Lee, Y.S.; Kim, H.-Y. Methionine sulfoxide reductase B in the endoplasmic reticulum is critical for stress resistance and aging in Drosophila. Biochem. Biophys. Res. Commun. 2012, 419, 20-26. [CrossRef]

22. Dos Santos, S.L.; Petropoulos, I.; Friguet, B. The oxidized protein repair enzymes methionine sulfoxide reductases and their roles in protecting against oxidative stress, in ageing and in regulating protein function. Antioxidants 2018, 7, 191. [CrossRef]

23. Moskovitz, J.; Bar-Noy, S.; Williams, W.M.; Requena, J.; Berlett, B.S.; Stadtman, E.R. Methionine sulfoxide reductase (MsrA) is a regulator of antioxidant defense and lifespan in mammals. Proc. Natl. Acad. Sci. USA 2001, 98, 12920-12925. [CrossRef]

24. Hansel, A.; Kuschel, L.; Hehl, S.; Lemke, C.; Agricola, H.J.; Hoshi, T.; Heinemann, S.H. Mitochondrial targeting of the human peptide methionine sulfoxide reductase (MSRA), an enzyme involved in the repair of oxidized proteins. FASEB J. 2002, 16,911-913. [CrossRef] [PubMed]

25. Vougier, S.; Mary, J.; Friguet, B. Subcellular localization of methionine sulphoxide reductase A (MsrA): Evidence for mitochondrial and cytosolic isoforms in rat liver cells. Biochem. J. 2003, 373, 531-537. [CrossRef]

26. Ruan, H.; Tang, X.D.; Chen, M.-L.; Joiner, M.-L.A.; Sun, G.; Brot, N.; Weissbach, H.; Heinemann, S.H.; Iverson, L.; Wu, C.-F.; et al. High-quality life extension by the enzyme peptide methionine sulfoxide reductase. Proc. Natl. Acad. Sci. USA 2002, 99, 2748-2753. [CrossRef] [PubMed]

27. Moskovitz, J.; Berlett, B.S.; Poston, J.M.; Stadtman, E.R. The Yeast Peptide-Methionine Sulfoxide Reductase Functions as an Antioxidant in vivo. Proc. Natl. Acad. Sci. USA 1997, 94, 9585-9589. [CrossRef]

28. Prentice, H.M.; Moench, I.A.; Rickaway, Z.T.; Dougherty, C.J.; Webster, K.A.; Weissbach, H. MsrA protects cardiac myocytes against hypoxia/reoxygenation induced cell death. Biochem. Biophys. Res. Commun. 2008, 366, 775-778. [CrossRef]

29. Moskovitz, J.; Flescher, E.; Berlett, B.S.; Azare, J.; Poston, J.M.; Stadtman, E.R. Overexpression of Peptide-Methionine Sulfoxide Reductase in Saccharomyces cerevisiae and Human T Cells Provides them with High Resistance to Oxidative Stress. Proc. Natl. Acad. Sci. USA 1998, 95, 14071-14075. [CrossRef]

30. Yermolaieva, O.; Xu, R.; Schinstock, C.; Brot, N.; Weissbach, H.; Heinemann, S.H.; Hoshi, T. Methionine sulfoxide reductase A protects neuronal cells against brief hypoxia/reoxygenation. Proc. Natl. Acad. Sci. USA 2004, 101, 1159-1164. [CrossRef]

31. Kantorow, M.; Hawse, J.R.; Cowell, T.L.; Benhamed, S.; Pizarro, G.O.; Reddy, V.N.; Hejtmancik, J.F. Methionine sulfoxide reductase A is important for lens cell viability and resistance to oxidative stress. Proc. Natl. Acad. Sci. USA 2004, 101, 9654-9659. [CrossRef] 
32. Picot, C.R.; Petropoulos, I.; Perichon, M.; Moreau, M.; Nizard, C.; Friguet, B. Overexpression of MsrA protects WI-38 SV40 human fibroblasts against H2O2-mediated oxidative stress. Free Radic. Biol. Med. 2005, 39, 1332-1341. [CrossRef]

33. Levine, R.L.; Berlett, B.S.; Moskovitz, J.; Mosoni, L.; Stadtman, E.R. Methionine residues may protect proteins from critical oxidative damage. Mech. Ageing Dev. 1999, 107, 323-332. [CrossRef]

34. Nan, C.; Li, Y.; Jean-Charles, P.-Y.; Chen, G.; Kreymerman, A.; Prentice, H.; Weissbach, H.; Huang, X. Deficiency of methionine sulfoxide reductase A causes cellular dysfunction and mitochondrial damage in cardiac myocytes under physical and oxidative stresses. Biochem. Biophys. Res. Commun. 2010, 402, 608-613. [CrossRef] [PubMed]

35. Boschi-Muller, S. Molecular mechanisms of the methionine sulfoxide reductase system from Neisseria meningitidis. Antioxidants 2018, 7, 131. [CrossRef] [PubMed]

36. Etienne, F.; Spector, D.; Brot, N.; Weissbach, H. A methionine sulfoxide reductase in Escherichia coli that reduces the R enantiomer of methionine sulfoxide. Biochem. Biophys. Res. Commun. 2003, 300, 378-382. [CrossRef]

37. Kwak, G.H.; Kim, J.R.; Kim, H.Y. Expression, subcellular localization, and antioxidant role of mammalian methionine sulfoxide reductases in Saccharomyces cerevisiae. BMB Rep. 2009, 42, 113-118. [CrossRef]

38. Kryukov, G.V.; Abhilash Kumar, R.; Koc, A.; Sun, Z.; Gladyshev, V.N. Selenoprotein R is a Zinc-Containing Stereo-Specific Methionine Sulfoxide Reductase. Source 2002, 99, 4245-4250. [CrossRef]

39. Abhilash Kumar, R.; Koc, A.; Cerny, R.L.; Gladyshev, V.N. Reaction mechanism, evolutionary analysis, and role of zinc in Drosophila methionine-R-sulfoxide reductase. J. Biol. Chem. 2002, 277, 37527-37535. [CrossRef] [PubMed]

40. Kim, H.-Y.; Gladyshev, V.N. Characterization of mouse endoplasmic reticulum methionine-R-sulfoxide reductase. Biochem. Biophys. Res. Commun. 2004, 320, 1277-1283. [CrossRef] [PubMed]

41. Koc, A.; Gasch, A.P.; Rutherford, J.C.; Kim, H.-Y.; Gladyshev, V.N. Methionine sulfoxide reductase regulation of yeast lifespan reveals reactive oxygen species-dependent and -independent components of aging. Proc. Natl. Acad. Sci. USA 2004, 101, 7999-8004. [CrossRef]

42. Shchedrina, V.A.; Kabil, H.; Vorbruggen, G.; Lee, B.C.; Turanov, A.A.; Hirosawa-Takamori, M.; Kim, H.-Y.; Harshman, L.G.; Hatfield, D.L.; Gladyshev, V.N. Analyses of fruit flies that do not express selenoproteins or express the mouse selenoprotein, methionine sulfoxide reductase B1, reveal a role of selenoproteins in stress resistance. J. Biol. Chem. 2011, 286, 29449-29461. [CrossRef] [PubMed]

43. Shchedrina, V.A.; Vorbrüggen, G.; Lee, B.C.; Kim, H.Y.; Kabil, H.; Harshman, L.G.; Gladyshev, V.N. Overexpression of methionineR-sulfoxide reductases has no influence on fruit fly aging. Mech. Ageing Dev. 2009, 130, 429-443. [CrossRef]

44. Cabreiro, F.; Picot, C.R.; Perichon, M.; Friguet, B.; Petropoulos, I. Overexpression of methionine sulfoxide reductases A and B2 protects MOLT-4 cells against zinc-induced oxidative stress. Antioxid. Redox Signal. 2009, 11, 215-225. [CrossRef] [PubMed]

45. Greer, E.L.; Brunet, A. FOXO transcription factors at the interface between longevity and tumor suppression. Oncogene 2005, 24, 7410-7425. [CrossRef]

46. Accili, D.; Arden, K.C. FoxOs at the crossroads of cellular metabolism, differentiation, and transformation. Cell 2004, 117, 421-426. [CrossRef]

47. Arden, K.C. FOXO animal models reveal a variety of diverse roles for FOXO transcription factors. Oncogene 2008, 27, 2345-2350. [CrossRef] [PubMed]

48. Wang, Z.; Yu, T.; Huang, P. Post-translational modifications of FOXO family proteins (Review). Mol. Med. Rep. 2016, 14, 4931-4941. [CrossRef] [PubMed]

49. Murtaza, G.; Khan, A.K.; Rashid, R.; Muneer, S.; Hasan, S.M.F.; Chen, J. FOXO Transcriptional Factors and Long-Term Living. Oxid. Med. Cell. Longev. 2017, 2017. [CrossRef]

50. Li, M.; Chiu, J.F.; Mossman, B.T.; Fukagawa, N.K. Down-regulation of manganese-superoxide dismutase through phosphorylation of FOXO3a by Akt in explanted vascular smooth muscle cells from old rats. J. Biol. Chem. 2006, 281, 40429-40439. [CrossRef]

51. Chung, Y.W.; Kim, H.K.; Kim, I.Y.; Yim, M.B.; Chock, P.B. Dual function of protein kinase C (PKC) in 12-O-tetradecanoylphorbol13- acetate (TPA)-induced manganese superoxide dismutase (MnSOD) expression: Activation of creb and foxo3a by PKC- $\alpha$ phosphorylation and by PKC-mediated inactivation of akt, respectively. J. Biol. Chem. 2011, 286, 29681-29690. [CrossRef]

52. Awad, H.; Nolette, N.; Hinton, M.; Dakshinamurti, S. AMPK and FoxO1 regulate catalase expression in hypoxic pulmonary arterial smooth muscle. Pediatr. Pulmonol. 2014, 49, 885-897. [CrossRef]

53. Yun, H.; Park, S.; Kim, M.J.; Yang, W.K.; Im, D.U.; Yang, K.R.; Hong, J.; Choe, W.; Kang, I.; Kim, S.S.; et al. AMP-activated protein kinase mediates the antioxidant effects of resveratrol through regulation of the transcription factor FoxO1. FEBS J. 2014, 281, 4421-4438. [CrossRef]

54. Venkatesan, B.; Mahimainathan, L.; Das, F.; Ghosh-Choudhury, N.; Choudhury, G.G. Downregulation of catalase by reactive oxygen species via PI 3 kinase/Akt signaling in mesangial cells. J. Cell. Physiol. 2007, 211, 457-467. [CrossRef] [PubMed]

55. Krivoruchko, A.; Storey, K.B. Anoxia-responsive regulation of the FoxO transcription factors in freshwater turtles, Trachemys scripta elegans. Biochim. Biophys. Acta 2013, 1830, 4990-4998. [CrossRef] [PubMed]

56. Minniti, A.N.; Cataldo, R.; Trigo, C.; Vasquez, L.; Mujica, P.; Leighton, F.; Inestrosa, N.C.; Aldunate, R. Methionine sulfoxide reductase A expression is regulated by the DAF-16/FOXO pathway in Caenorhabditis elegans. Aging Cell 2009, 8, 690-705. [CrossRef]

57. Chung, H.; Kim, A.K.; Jung, S.A.; Kim, S.W.; Yu, K.; Lee, J.H. The Drosophila homolog of methionine sulfoxide reductase A extends lifespan and increases nuclear localization of FOXO. FEBS Lett. 2010, 584, 3609-3614. [CrossRef] 
58. Reiterer, M.; Milton, S.L. Induction of foxo3a protects turtle neurons against oxidative stress. Comp. Biochem. Physiol. Part A Mol. Integr. Physiol. 2020, 243, 110671. [CrossRef]

59. Bartholome, A.; Kampkötter, A.; Tanner, S.; Sies, H.; Klotz, L.O. Epigallocatechin gallate-induced modulation of FoxO signaling in mammalian cells and C. elegans: FoxO stimulation is masked via PI3K/Akt activation by hydrogen peroxide formed in cell culture. Arch. Biochem. Biophys. 2010, 501, 58-64. [CrossRef]

60. Brunet, A.; Bonni, A.; Zigmond, M.J.; Lin, M.Z.; Juo, P.; Hu, L.S.; Anderson, M.J.; Arden, K.C.; Blenis, J.; Greenberg, M.E. Akt promotes cell survival by phosphorylating and inhibiting a forkhead transcription factor. Cell 1999, 96, 857-868. [CrossRef]

61. Jahn, A.; Scherer, B.; Fritz, G.; Honnen, S. Statins Induce a DAF-16/Foxo-dependent longevity phenotype via JNK-1 through Mevalonate depletion in C. elegans. Aging Dis. 2020, 11, 60-72. [CrossRef]

62. Lee, B.C.; Dikiy, A.; Kim, H.-Y.; Gladyshev, V.N. Functions and evolution of selenoprotein methionine sulfoxide reductases. Biochim. Biophys. Acta 2009, 1790, 1471-1477. [CrossRef]

63. Martins, R.; Lithgow, G.J.; Link, W. Long live FOXO: Unraveling the role of FOXO proteins in aging and longevity. Aging Cell 2016, 15, 196-207. [CrossRef]

64. Nayak, G.; Prentice, H.M.; Milton, S.L. Lessons from nature: Signalling cascades associated with vertebrate brain anoxic survival. Exp. Physiol. 2016, 101, 1185-1190. [CrossRef] [PubMed]

65. Prentice, H.M.; Milton, S.L.; Scheurle, D.; Lutz, P.L. The upregulation of cognate and inducible heat shock proteins in the anoxic turtle brain. J. Cereb. Blood Flow Metab. 2004, 24, 826-828. [CrossRef] [PubMed]

66. van Breukelen, F.; Maier, R.; Hand, S.C. Depression of nuclear transcription and extension of mRNA half-life under anoxia in Artemia franciscana embryos. J. Exp. Biol. 2000, 203, 1123-1130. [CrossRef] [PubMed]

67. Fraser, K.P.; Houlihan, D.F.; Lutz, P.L.; Leone-Kabler, S.; Manuel, L.; Brechin, J.G. Complete suppression of protein synthesis during anoxia with no post-anoxia protein synthesis debt in the red-eared slider turtle Trachemys scripta elegans. J. Exp. Biol. 2001, 204, 4353-4360. [CrossRef]

68. van Breukelen, F.; Martin, S.L. Reversible depression of transcription during hibernation. J. Comp. Physiol. B 2002, 172, 355-361. [CrossRef]

69. Osborne, P.G.; Gao, B.; Hashimoto, M. Determination in vivo of newly synthesized gene expression in hamsters during phases of the hibernation cycle. Jpn. J. Physiol. 2004, 54, 295-305. [CrossRef]

70. Kesaraju, S.; Schmidt-Kastner, R.; Prentice, H.M.; Milton, S.L. Modulation of stress proteins and apoptotic regulators in the anoxia tolerant turtle brain. J. Neurochem. 2009, 109, 1413-1426. [CrossRef]

71. Storey, K.B. Anoxia tolerance in turtles: Metabolic regulation and gene expression. Comp. Biochem. Physiol. A Mol. Integr. Physiol. 2007, 147, 263-276. [CrossRef]

72. Pamenter, M.E.; Richards, M.D.; Buck, L.T. Anoxia-induced changes in reactive oxygen species and cyclic nucleotides in the painted turtle. J. Comp. Physiol. B 2007, 177, 473-481. [CrossRef] [PubMed]

73. Lutz, P.L.; Prentice, H.M.; Milton, S.L. Is turtle longevity linked to enhanced mechanisms for surviving brain anoxia and reoxygenation? Exp. Gerontol. 2003, 38, 797-800. [CrossRef]

74. Giraud-Billoud, M.; Rivera-Ingraham, G.A.; Moreira, D.C.; Burmester, T.; Castro-Vazquez, A.; Carvajalino-Fernández, J.M.; Dafre, A.; Niu, C.; Tremblay, N.; Paital, B.; et al. Twenty years of the 'Preparation for Oxidative Stress' (POS) theory: Ecophysiological advantages and molecular strategies. Comp. Biochem. Physiol. Part. A Mol. Integr. Physiol. 2019, 234, 36-49. [CrossRef] [PubMed]

75. Marchetti, M.A.; Pizarro, G.O.; Sagher, D.; Deamicis, C.; Brot, N.; Hejtmancik, J.F.; Weissbach, H.; Kantorow, M. Methionine sulfoxide reductases B1, B2, and B3 are present in the human lens and confer oxidative stress resistance to lens cells. Investig. Ophthalmol. Vis. Sci. 2005, 46, 2107-2112. [CrossRef] [PubMed]

76. Bruce, L.; Singkornrat, D.; Wilson, K.; Hausman, W.; Robbins, K.; Huang, L.; Foss, K.; Binninger, D. In vivo effects of methionine sulfoxide reductase deficiency in Drosophila melanogaster. Antioxidants 2018, 7, 155. [CrossRef]

77. Salmon, A.B.; Pérez, V.I.; Bokov, A.; Jernigan, A.; Kim, G.; Zhao, H.; Levine, R.L.; Richardson, A. Lack of methionine sulfoxide reductase $\mathrm{A}$ in mice increases sensitivity to oxidative stress but does not diminish life span. FASEB J. 2009, 23, 3601-3608. [CrossRef]

78. Moskovitz, J.; Malik, A.; Hernandez, A.; Band, M.; Avivi, A. Methionine sulfoxide reductases and methionine sulfoxide in the subterranean mole rat (Spalax): Characterization of expression under various oxygen conditions. Comp. Biochem. Physiol. A Mol. Integr. Physiol. 2012, 161, 406-414. [CrossRef]

79. Shams, I.; Avivi, A.; Nevo, E. Hypoxic stress tolerance of the blind subterranean mole rat: Expression of erythropoietin and hypoxia-inducible factor $1 \alpha$. Proc. Natl. Acad. Sci. USA 2004, 101, 9698-9703. [CrossRef]

80. Shams, I.; Avivi, A.; Nevo, E. Oxygen and carbon dioxide fluctuations in burrows of subterranean blind mole rats indicate tolerance to hypoxic-hypercapnic stresses. Comp. Biochem. Physiol. A. Mol. Integr. Physiol. 2005, 142, 376-382. [CrossRef]

81. Bergeron, M.; Yu, A.Y.; Solway, K.E.; Semenza, G.L.; Sharp, F.R. Induction of hypoxia-inducible factor-1 (HIF-1) and its target genes following focal ischaemia in rat brain. Eur. J. Neurosci. 1999, 11, 4159-4170. [CrossRef]

82. Semenza, G.L. Hypoxia-inducible factor 1 (HIF-1) pathway. Sci. STKE 2007, 2007, cm8. [CrossRef]

83. Prentice, H.M.; Milton, S.L.; Scheurle, D.; Lutz, P.L. Gene transcription of brain voltage-gated potassium channels is reversibly regulated by oxygen supply. Am. J. Physiol. Regul. Integr. Comp. Physiol. 2003, 285, R1317-R1321. [CrossRef]

84. Kesaraju, S. Molecular Mechanisms of Neuroprotection in the Anoxia Tolerant Freshwater Turtle; Florida Atlantic University: Boca Raton, FL, USA, 2008. 
85. Rissanen, E.; Tranberg, H.K.; Sollid, J.; Nilsson, G.E.; Nikinmaa, M. Temperature regulates hypoxia-inducible factor-1 (HIF-1) in a poikilothermic vertebrate, crucian carp (Carassius carassius). J. Exp. Biol. 2006, 209, 994-1003. [CrossRef]

86. Ji, C.; Zhang, N.; Jiang, H.; Meng, X.; Ge, H.; Yang, X.; Xu, X.; Qian, K.; Park, Y.; Zheng, Y.; et al. 20-hydroxyecdysone regulates expression of methioninesulfoxide reductases through transcription factor FOXO in the red flour beetle, Tribolium castaneum. Insect Biochem. Mol. Biol. 2021, 131. [CrossRef] [PubMed]

87. Kops, G.J.P.L.; Dansen, T.B.; Polderman, P.E.; Saarloos, I.; Wirtz, K.W.A.; Coffer, P.J.; Huang, T.T.; Bos, J.L.; Medema, R.H.; Burgering, B.M.T. Forkhead transcription factor FOXO3a protects quiescent cells from oxidative stress. Nature 2002, 419, 316-321. [CrossRef]

88. Honda, Y.; Honda, S. The daf-2 gene network for longevity regulates oxidative stress resistance and Mn-superoxide dismutase gene expression in Caenorhabditis elegans. FASEB J. 1999, 13, 1385-1393. [CrossRef]

89. Brunet, A.; Sweeney, L.B.; Sturgill, J.F.; Chua, K.F.; Greer, P.L.; Lin, Y.; Tran, H.; Ross, S.E.; Mostoslavsky, R.; Cohen, H.Y.; et al. Stress-Dependent Regulation of FOXO Transcription Factors by the SIRT1 Deacetylase. Science 2004, 303, 2011-2015. [CrossRef]

90. Kobayashi, Y.; Furukawa-Hibi, Y.; Chen, C.; Horio, Y.; Isobe, K.; Ikeda, K.; Motoyama, N. SIRT1 is critical regulator of FOXOmediated transcription in response to oxidative stress. Int. J. Mol. Med. 2005, 16, 237-243. [CrossRef] [PubMed]

91. Ramaswamy, S.; Nakamura, N.; Vazquez, F.; Batt, D.B.; Perera, S.; Roberts, T.M.; Sellers, W.R. Regulation of G1 progression by the PTEN tumor suppressor protein is linked to inhibition of the phosphatidylinositol 3-kinase/akt pathway. Proc. Natl. Acad. Sci. USA 1999, 96, 2110-2115. [CrossRef]

92. Wang, Z.; Liu, Y.; Liu, X.; Zhou, L.; Ma, X.; Liu, J.; Wang, L.; Guo, H. Activation of forkhead box O3a by mono(2ethylhexyl)phthalate and its role in protection against mono(2-ethylhexyl)phthalate-induced oxidative stress and apoptosis in human cardiomyocytes. J. Appl. Toxicol. 2021, 41, 618-631. [CrossRef] [PubMed]

93. Nemoto, S.; Finkel, T. Redox regulation of forkhead proteins through a p66shc-dependent signaling pathway. Science 2002, 295, 2450-2452. [CrossRef] [PubMed]

94. Cudic, P.; Joshi, N.; Sagher, D.; Williams, B.T.; Stawikowski, M.J.; Weissbach, H. Identification of activators of methionine sulfoxide reductases A and B. Biochem. Biophys. Res. Commun. 2016, 469, 863-867. [CrossRef]

95. Roesijadi, G.; Rezvankhah, S.; Binninger, D.M.; Weissbach, H. Ecdysone induction of MsrA protects against oxidative stress in Drosophila. Biochem. Biophys. Res. Commun. 2007, 354, 511-516. [CrossRef]

96. Picot, C.R.; Perichon, M.; Lundberg, K.C.; Friguet, B.; Szweda, L.I.; Petropoulos, I. Alterations in mitochondrial and cytosolic methionine sulfoxide reductase activity during cardiac ischemia and reperfusion. Exp. Gerontol. 2006, 41, 663-667. [CrossRef] [PubMed]

97. Moskovitz, J.; Stadtman, E.R. Selenium-deficient diet enhances protein oxidation and affects methionine sulfoxide reductase (MsrB) protein level in certain mouse tissues. Proc. Natl. Acad. Sci. USA 2003, 100, 7486-7490. [CrossRef] [PubMed]

98. Reiterer, M.; Schmidt-Kastner, R.; Milton, S.L. Methionine sulfoxide reductase (Msr) dysfunction in human brain disease. Free Radic. Res. 2019, 53. [CrossRef] [PubMed] 